\title{
Discussion on the Construction of the Operation Mechanism of Enterprise Cooperation based on Interest Driven
}

\author{
Junnan Yi1,* \\ Xijing University, Xi'an, 710123, China \\ Email: 516608324@qq.com
}

\begin{abstract}
This paper set about from the necessity of university-enterprise cooperation platform construction, through the study of the definition, classification of university-enterprise cooperation platform, from constructing university-enterprise cooperation, enhance the school to attract the interests of the chain enterprises participate in university-enterprise cooperation motivation, some Suggestions on perfecting the operating mechanism of university-enterprise cooperation platform. The approach of constructing university-enterprise cooperation platform, aims to promote the depth of the cooperation between colleges.
\end{abstract}

Keywords-Interest; Platform; University-enterprise cooperation; Higher vocational colleges

\section{INTRODUCTION}

At present, many higher vocational colleges in the process of university-enterprise cooperation no fixed place of communication and information communication channel, also did not form some effective operation mechanism and the interests of the chain to our mutual benefit, did not form a cooperative organization, entity or information platform. In the case of this lack of interactive exchanges and cooperation platform $s[1]$, the contact between the two sides is not much, knew little, often only in one's credentials the exercise need to carry out the field work, and the matters such as business experts to guide, to make some contact. University-enterprise cooperation at this time were mostly temporary, the shallow level of periodic university-enterprise cooperation, therefore, it is difficult to enter the discussion and research on some indepth and sustained cooperation in the field of stage, the cultural fusion, advantage complementary resources between colleges simply impossible s[2-4]. Therefore, how to build effective platform for the cooperation between colleges, effectively integrate the enterprise, industry, social resources, to gradually improve the quality of higher vocational education is essential s[5-6].

\section{THE DEFINITION OF UNIVERSITY-ENTERPRISE COOPERATION PLATFORM}

Platform to work on a project often refers to the need of the environment or conditions. With the aid of the platform, people can communicate, learn, trading, such as interactive work, such as organization platforms, technology platform, building platform, information platform, etc. University-enterprise cooperation platform, therefore, should also is a kind of environment or

\author{
Shidan $\mathrm{He} 2$ \\ Xijing University, Xi'an, 710123, China \\ Email: 315705804@qq.com
}

conditions, is to help participants university-enterprise cooperation communication, information sharing, personnel training, scientific research, technology popularization and application of the environment or conditions[7]. Through the university-enterprise cooperation platform, university-enterprise cooperation not involved to establish common values, for the interests of the public demands, through the information exchange, resource sharing and complementary advantages, to achieve win-win cooperation and common development [8].

the kinds of university-enterprise cooperation platform construction

Only through corresponding university-enterprise cooperation platform in higher vocational colleges, and master and dominate the most extensive social resources of the government, industry, enterprise for effective cooperation, in order to embody vocational education and economic society, industry enterprise most closely, most direct distinctive characteristics, to promote sustainable development of higher vocational education. Combining higher vocational colleges at present, the school's own characteristics and has the advantages of constructing university-enterprise cooperation platform, explore and practice by multilateral cooperation and integration development, integration of resources to the most extensive education and society.

Based on the research of the existing various cooperation platform between colleges, according to different classification standards, found of platforms have different classification. Now according to the platform exists in the form of classification, generally has the following three categories.

\section{A. The organization platform}

Regional cooperation committee. Is within a certain geographical area of university-enterprise cooperation management institutions, mainly be responsible for the formulation of university-enterprise cooperation in the area of the job planning, coordination of enterprise and school personnel training in the area of relationship. The school university-enterprise cooperation office, set up through regional cooperation committee to bridge the communication between schools and enterprises.

Cooperation and development council. Is a multi-level and multi-field university-enterprise cooperation organization platform, is driven by the government, led by the competent department of industry, college as the main body, enterprises as the standing director unit, attracting 
the participation of industry association, the play in the strategic positioning, development planning, the recruitment of students employment, personnel training, scientific research, technology popularization and application of consultation, the function of procedure, guidance and decision-making. Vocational education group (alliance). Is the collection of education teaching and training, scientific research, technical services, personnel training and project cooperation as one of the non-profit unincorporated society organizations. Through the formation of vocational education group (alliance), can rely on industry, in accordance with the "government guidance, leading backbone, university-university joint, university-enterprise cooperation, mutual benefit and winwin" requirement, build equality, cooperation, resource sharing the interests of the community, promote between higher vocational colleges and universities, colleges and universities with complementary advantages and common development between enterprises.

Mix branch. By industry experts and scholars in the field of enterprise technology, industry executives and members, such as school teachers have the characteristics of both school and enterprise business community organizations and teaching, promote the full-time teachers professional education teaching ability promotion and parttime teachers' teaching task the labor of the enterprise, meet the school personnel training, enterprise employees' professional ability and quality promotion and the need of social services.

\section{B. The entity platform}

The productive practice base. To guide enterprises enrolled in higher vocational colleges, the school provides meets the needs of the enterprise site, equipment and environment, and connecting with the enterprise practice, the corresponding practical courses into the whole teaching system; Provided by the enterprise according to the requirements of production construction standard production workshop, processing products of raw materials, help the school set up training course system, guide the practice of teachers and students are related to the production and practice, be responsible for the management of the training base on production and management.

University-enterprise cooperation of secondary school. The joint between colleges is responsible for the secondary school of goal orientation, development planning, personnel training and other major matters of the decision; Enterprises with huge amount of money is responsible for running the required hardware, including the campus facilities, equipment, logistics facilities and logistics service, etc.; Teachers in higher vocational colleges is mainly responsible for software development, including hiring, graduated from admissions to the whole process of management, etc. Between the two sides made up of members of the management team, coordinate in routine college; By professional steering committee, responsible for the professional construction, course construction, teachers construction, teaching and training provide consultation and guidance.

Between teaching factory. From between the two sides to build, at the scene of the enterprise in accordance with the process of teaching, post skills training and advanced technological process to set up the functional areas, forming reality teaching platform, and thus have teaching, training, training, and display function, promote the teaching process and the production process of close docking, realize the school theory and in combination with the real business practice, thus systematically cultivating students' professional ability and professional quality.

Engineering center (institute). Is the school by signing a cooperation agreement with cooperative enterprise, in school or in the enterprise set up a joint, members mainly schools have corresponding professional specialty and can meet the demand of enterprise technology industry experts, teachers and enterprises formed between the two sides Shared intelligence and technical resources. Engineering center can solve the technical problem for the enterprise, can also with the help of the enterprise technical force joint research on industry of hot issues and technical application class project, improve the ability of production, higher vocational colleges and the ability to serve the society.

\section{The information platform}

Information platform can be a network communication platform, can also be a solid platform of information management platform and supporting services platform. Through the information platform, the school can provide graduates job related information, and select suitable employees is helpful for enterprises to carry out targeted; Enterprise can release recruitment information, will be conducive to the graduates' employment; Schools and teachers can publish professional construction, to provide intellectual support for the enterprise; Science and technology department can publish enterprise technical problem, higher personnel training needs, for schools to get scientific data and research instance, unblocking industry-university-institute cooperation; The policy of the government can publish industry and information technology, production and supply and demand information and human resources information, so as to promote information sharing, achieve the public service function. Should say information platform is the key to ensure the efficient, timely and open information, so that the university-enterprise cooperation information more transparent, more convenient to communicate.

If divided according to the function of the platform, the entity platform and can be divided into for the purpose of personnel training, secondary school, etc., between teaching factory staff training as functions of the campus teaching base and technical services as the function of engineering center and other categories; If the platform of the main body, can be divided into government, school, enterprise multi-agent together form of vocational education group (vocational education alliance), with common between colleges as the main body of the secondary school, branch, etc., mixed with enterprises as the main body of teaching workshop commander (factory), as the main body of the campus to produce teaching base (factory) in the school and other categories. Universityenterprise cooperation platform, of course, sometimes it is a complex, at the same time, including the organization platform, entity platform, the information platform of form and function. 


\section{THE APPROACH OF CONSTRUCTING UNIVERSITY- ENTERPRISE COOPERATION PLATFORM}

Should, for the sake of enhancing university-enterprise cooperation, the current university-enterprise cooperation organization or communication platform in a variety of forms, various, however most formal, go through the motions, and present one-sided enthusiasm a thermal head of state in higher vocational colleges, and weak enterprise participation enthusiasm. The reason is that do not match the interests between the two sides, more is the enterprise is not fully enjoy the benefits in the cooperation, what's more feelings have been unilaterally pay, interests will be damaged in the cooperation, so no way to realize the winwin cooperation between colleges and long-lasting. In order to promote the effective operation of universityenterprise cooperation platform, play to the role of the platform, promote university-enterprise cooperation depth fusion, should consider the following points:

\section{A. . To establish the interests of the chain}

The fundamental source of interest is a driving force to produce cooperation, through the analysis of universityenterprise cooperation on the effects of enterprise and school respectively, in the platform construction between colleges, between the main body of the value of each other's common orientation, views and interests, find the interests of the combining site, build the interests of mutual benefit and win-win cooperation chain. For the school, through the university-enterprise cooperation, can in time understanding and grasping the latest demand, technical requirements; Can be effectively integrated industry, enterprises of all kinds of resources, which would be helpful to the professional construction of vocational colleges, "double teacher quality", the construction of the contingent of teachers, the improvement of the education teaching conditions, targeted to carry out the education teaching reform, improve the quality of personnel training, to realize the zero distance of employment of graduates; But experts in technology application research with industry enterprise, implementation technology service, social service function. For enterprises, through the cooperation between colleges, higher vocational colleges can take advantage of the high quality of teachers and professional advantages to raising staff theory and skill training; Can be tailored to meet business requirements, conforms to the enterprise culture of the high-end technology skilled talents; Higher vocational colleges can rely on intellectual resources for enterprises to solve technical problems, improve enterprise's technical strength; Can also be based on a many-to-many universityenterprise cooperation, in the industry establish a good corporate image, expand the publicity effect. For governments, can with the power of university-enterprise cooperation to carry out social services, promote to speed up the transformation of the mode of economic development of the technology application of countermeasure research, promoting regional economic transformation and upgrading.

\section{B. Increase the charm of schools to attract enterprises to cooperate}

For higher vocational colleges, if school idea conservative, lack of double quality teacher, unable to help enterprises solve the problem such as product development and technical research, personnel training level is not high, can not adapt to market changes and meet the needs of the enterprise, will not be able to attract companies interested in cooperation filed. Therefore, schools need to strengthen the training mode innovation, enterprise talent demand oriented to promote the reform of teaching, through the communication with the industry association, in-depth enterprise, actively know the market in time for the actual demand for talent specification, quantity, improve the quality of personnel training and the recognition of the society, pay attention to the connotation construction, form their own characteristics, the cultivation core competitiveness s[9]; To strengthen the construction of dual teacher quality of teachers, let the professional teachers not only have abundant professional theory knowledge, solid professional practice skills and experience, always follow the enterprise constantly updated technology and management methods, and application in the teaching and scientific research in a timely manner; To strengthen the service consciousness, can according to the different needs of enterprises, to provide different services. Qualified skilled talents for the enterprise, such as school graduates can seamless docking jobs; The school provides consultation, guidance and other services; School for the enterprise to carry out skills training, vocational qualification, equipment modification, technology research, research method, etc. To enhance school attract the charm of the enterprise, stimulate the motive force of the enterprises, encourage enterprises to actively participate in university-enterprise cooperation, enthusiasm and continue to maintain cooperation $\mathrm{s}$ [10].

\section{To improve the operating mechanism of university- enterprise cooperation platform}

It is easy to building a Platform but more difficult. to realize effective operation. Therefore, higher vocational colleges should pay more attention to the platform of build effective operation later s[11].If there is information asymmetry in the process of enterprise cooperation between enterprises, human capital investment, the lack of incentive evaluation, the definition of property rights and other phenomena, it will lead to enterprises[12] , vocational colleges and universities to carry out the power shortage of school enterprise cooperation.

\section{CONCLUSIONS}

Therefore, in the mechanism, the rights and obligations of the parties shall be clearly defined; shall establish a dispute settlement mechanism, when the interests of all parties to produce conflict, can coordinate to solve; Should build perfect management and operation system, to ensure that the cooperation in the process of information communication, understand the demand of cooperation, to realize the purpose of the cooperation; improve universityenterprise cooperation evaluation system constantly, through the classification, component analysis and comprehensive analysis of state of the process of cooperation, the cooperation stage, cooperation, cooperation benefits and cooperation results are quantitative and qualitative evaluation; Should constantly improve the system of incentive evaluation, pay more attention to the teachers and staff of part in university- 
enterprise cooperation work assessment, assessment and incentive, improve their willingness to participate in university-enterprise cooperation and responsibility.

\section{REFERENCES}

[1] H. Goto, Y. Hasegawa, and M. Tanaka, "Efficient Scheduling Focusing on the Duality of MPL Representatives," Proc. IEEE Symp. Computational Intelligence in Scheduling (SCIS 07), IEEE Press, Dec. 2007, pp. 57-64, doi:10.1109/SCIS.2007.357670.

[2] Abramovsky, L., Simpson, H., 2011. Geographic proximity and firm-university innovation linkages: evidence from Great Britain. J. Econ. Geogr. 11,949-977.

[3] Adkins, L., 2012. Testing parameter significance in instrumental variables probit estimators: some simulation results. J. Stat. Comput. Simul. 83 (10),1415-1436.

[4] International Comparisons in Computing and Biotechnology. Oxford UniversityPress, Oxford, pp. 13-51.

[5] Barge-Gil, A., 2010. Cooperation-based innovators and peripheral cooperators: anempirical analysis of their characteristics and behavior. Technovation 30,195-206.
[6] Barge-Gil, A., 2013. Open strategies and innovation performance. Ind. Innov. 20 (7),585-610.

[7] Barge-Gil, A., Modrego, A., 2011. The impact of research and technology organizations on firm competitiveness. Measurement and determinants. J.Technol. Transf. 36, 61-83.

[8] Barge-Gil, A., Santamaría, L., Nieto, M.J., 2011. Hidden innovators. The role of non-R\&D activities. Technol. Anal. Strateg. Manag. 23 (4), 415-432.

[9] Bascle, G., 2008. Controlling for endogeneity with instrumental variables in strategic management research. Strateg. Org. 6, 285327.

[10] Basile, A., 2011. Networking system and innovation outputs: the role of Scienceand Technology Parks. Int. J. Bus. Manag. 6 (5), 3 14.

[11] Bennet, R.J., Bratton, W.A., Robson, P.J., 2000. Business advice: the influence of distance. Reg. Stud. 34 (9), 813-828.

[12] Bigliardi, B., Ivo Dormio, A., Nosella, A., Petroni, G., 2006. Assessing science parks'performances: directions from selected Italian case studies. Technovation26(4),489-50 